\title{
Characterization of Oil Yield and Quality in Shatter-Resistant Dwarf Sesame Produced in Virginia, USA
}

\author{
Harbans L. Bhardwaj ${ }^{1}$, Anwar A. Hamama ${ }^{1}$, Mark E. Kraemer ${ }^{1} \&$ D. Ray Langham ${ }^{2}$ \\ ${ }^{1}$ Agricultural Research Station, Virginia State University, Petersburg, Virginia, USA \\ ${ }^{2}$ Sesaco Corporation, San Antonio, Texas, USA \\ Correspondence: Harbans L. Bhardwaj, Agricultural Research Station, Virginia State University, Petersburg, \\ Virginia 23806, USA. Tel: 1-804-524-6723. E-mail: hbhardwj@vsu.edu
}

\author{
Received: December 9, 2014 Accepted: February 3, 2015 Online Published: March 15, 2015 \\ doi:10.5539/jas.v7n4p87 \\ URL: http://dx.doi.org/10.5539/jas.v7n4p87
}

\begin{abstract}
Sesame has potential as an alternative crop for former tobacco farmers in eastern USA to increase agricultural diversification and enhance farm incomes. Oil yield and quality of five shatter-resistant and dwarf sesame cultivars when grown using rows $37.5 \mathrm{~cm}$ or $75 \mathrm{~cm}$ apart were evaluated. Sesame was planted on 23 May and 8 Jun. (PT1) during 2011 and on 17 and 9 Jul. (PT2) during 2012. Early planting (Late May to early June) resulted in $716.6 \mathrm{~kg}$ oil $/$ ha as compared to $479.6 \mathrm{~kg}$ oil/ha from late planting (early June to mid-July). The closer row spacing of $37.5 \mathrm{~cm}$ out-yielded the wider row spacing of $75 \mathrm{~cm}$ by about $34 \%$ for oil yield. Early planting increased the contents of C16:0, C20:0, C18:1, and C20:1 fatty acids whereas late planting increased the contents of C18:2 and C18:3 fatty acids. Contents of total saturated fatty acids and mono-unsaturated fatty acids were also greater after early planting as compared to those after late plantings. Closer row spacing of $37.5 \mathrm{~cm}$ resulted in significantly higher contents of $\mathrm{C} 20: 1$ and saturated fatty acids in the oil as compared to the wider row spacing of $75 \mathrm{~cm}$. Sesame seed produced in Virginia contained $6.8 \%$ more oil than that produced in Texas (45. 5 vs. $42.6 \%$, respectively). The results indicated that sesame could be produced in the mid-Atlantic region of USA.
\end{abstract}

Keywords: Sesamum indicum L., fatty acids, oil yield, planting dates, row spacings, new crops

\section{Introduction}

Sesame (Sesamum indicum L. Pedaliaceae) is one of the oldest crops known to humans. There are archeological remnants of sesame dating to 5,500 BP in the Harappa valley in the Indian subcontinent (Bedigian \& Harlan, 1986). Sesame was a major oilseed in the ancient world because of its ease of extraction, its great stability, and its drought resistance. Through the ages, sesame seeds have been a source of food and oil, about $65 \%$ of the annual sesame crop is processed into oil and the remainder is used in food (AgMRC, 2013). In the United States, sesame seed production has been limited to the Southwest, primarily due to the lack of mechanically harvestable cultivars suited to other climates. Almost all commercial production is in Texas and Oklahoma. In 2007, sesame was grown commercially on 29 farms, 25 of them were in Texas and the remaining four were in Oklahoma. All together, U.S. sesame farms produced over 2.9 million pounds of sesame during 2007, on about 4,978 acre (in contrast, less than 2,500 acres were planted to sesame in 1987). The pounds of sesame have doubled since 2002, with the addition of only seven farms. Most U.S. sesame is grown on contract (USDA, 2009).

Sesame was introduced to the US from Africa and was called beni/benne/benni. Betts (1999) quotes letters from Thomas Jefferson that document his trials with sesame between 1808 and 1824. Jefferson stated that sesame “... is among the most valuable acquisitions our country has ever made. ... I do not believe before that there existed so perfect a substitute for olive oil" (Langham \& Wiemers, 2002). In the 1940s, research was started in South Carolina (Martin, 1949), Nebraska (Hoffman \& Claassen, 1949), and Texas (Kalton, 1949). A major issue with sesame was its' tendency to shatter. In 1978, Sesaco, Inc. was established to bring D.G. Langham's work from Venezuela to the US. However, it became clear that in the US complete mechanization would be necessary. By 1982, the first mechanized cultivars were released (Langham \& Wiemers, 2002). In 2010, Sesaco had more than 100,000 acres of sesame under contract production with growers in southwest Kansas, Oklahoma and central Texas. This production has been facilitated by availability of dwarf, shatter-resistant sesame cultivars.

International demand for sesame continues to increase every year. The world's traded sesame seed recently 
surpassed one million tons per year and was valued at approximately $\$ 850$ million. In the last 15 years, world trade in sesame has increased by nearly 80 percent. The United States imports more sesame than it grows. In 2010 , the United States imported sesame seed valued at $\$ 69.9$ million which was relatively unchanged from 2009 (AgMRC, 2013). This observation indicates that there is potential for enhancing sesame production in the United States.

Due to loss of tobacco and other crops such as peanut (Arachis hypogea L.), the New Crops Program of Virginia State University has been evaluating several summer crops that can be grown in Virginia to increase agricultural diversification and enhance farm incomes. In this regard, sesame (Sesamum indicum L. Pedaliaceae) is considered a potentially lucrative crop due to its use in foods including the production of hummus. Goals of the current research effort were to determine if sesame could be successfully produced in Virginia. Specifically, the objectives were evaluation of sesame cultivars for their oil yields and characterization of the effects of planting date and row spacing on the oil and fatty acid content in sesame seed.

\section{Materials and Methods}

\subsection{Plant Material}

Five proprietary sesame cultivars (22K, S26, S28, S30, and S32) from Sesaco Corporation (San Antonio, Texas, USA) were used in this study. These cultivars are dwarf and shatter-resistant and are intellectual property of Sesaco, Inc. (San Antonio, Texas, USA). These were the only shatter-resistant cultivars available to us for our studies. We were interested only in shatter-resistant cultivars because these cultivars can be mechanically harvested as compared to traditional cultivars that shatter and need to be harvested manually.

\subsection{Plant Production}

This field study was conducted at Randolph Farm of Virginia State University located in Ettrick, Virginia. The five cultivars were planted in four-row plots with row spacings of 37.5 and $75 \mathrm{~cm}$ in an Abel Sandy Loam soil. Sesame was planted on 23 May and 8 Jun. (PT1) during 2011 and on 17 and 9 Jul. (PT2) during 2012 using a split-plot experimental design with planting dates as main plots, row spacings as sub-plots and cultivars as sub-sub-plots with four replications of a Randomized Complete Block Design. The experimental field received a pre-plant incorporated application of approximately 2 liters of Trifluralin herbicide per hectare. The experimental area received a fertilizer application of $112 \mathrm{~kg}$ per hectare of $\mathrm{N}, \mathrm{P}$, and $\mathrm{K}$. All plots were harvested manually at maturity, generally in November to December of each year.

\subsection{Oil extraction, Preparation and Analysis of FAME}

The oil was extracted from $1 \mathrm{~g}$ of ground seed at room temperature by homogenization for $2 \mathrm{~min}$ in $10 \mathrm{~mL}$ hexane/isopropanol (3:2, v/v) with a Biospec Model 985-370 Tissue Homogenizer (Biospec Products, Inc. Racine, WI, USA) and centrifuged at $4000 \mathrm{~g}$ for $5 \mathrm{~min}$, as described by Hamama et al. (2005). The oil extraction was repeated for each sample for three times to ensure full oil recovery and the three extractions were combined. The hexane-lipid layer was washed and separated from the combined extract by shaking and centrifugation with $10 \mathrm{~mL}$ of $1 \% \mathrm{CaCl}_{2}$ and $1 \% \mathrm{NaCl}$ in $50 \%$ methanol. The washing procedure was repeated and the purified lipid layer was removed by aspiration and dried over anhydrous $\mathrm{Na}_{2} \mathrm{SO}_{4}$. The oil was stored under nitrogen at $-10{ }^{\circ} \mathrm{C}$ until analysis.

Fatty Acid Methyl Esters (FAME) were prepared by an acid-catalyzed transestrification method as described by Hamama et al. (2005). The oil samples (5 mg) were vortexed with $2 \mathrm{~mL}$ sulfuric acid/methanol $(1: 99, \mathrm{v} / \mathrm{v})$ in 10 -mL glass vials containing a Teflon boiling chip. The open vials were placed in a heating block at $90{ }^{\circ} \mathrm{C}$ until the sample volume was reduced to $0.5 \mathrm{~mL}$. After cooling to room temperature, $1 \mathrm{~mL}$ of hexane, followed by 1 $\mathrm{mL}$ of distilled water was added. The mixture was vortexed and the upper hexane layer containing the FAME was taken and dried over anhydrous $\mathrm{Na}_{2} \mathrm{SO}_{4}$. The hexane phase containing FAME was transferred to a suitable vial and kept under $\mathrm{N}_{2}$ at $0{ }^{\circ} \mathrm{C}$ for gas chromatographic analysis.

Analyses of FAME were carried out as described by Hamama et al. (2005) using a SupelcoWax 10 capillary column $(25 \mathrm{~m} \times 0.25 \mathrm{~mm}$ i.d. and $0.25 \mathrm{~mm}$ film thickness, SupelcoWax, Inc., Bellefonte, PA, USA $)$ in a Varian model Vista 6000 GC equipped with a Flame Ionization Detector (FID) (Varian, Sugar Land, TX, USA). An SP-4290 Integrator (Spectra Physics, San Jose, CA, USA) was used to determine relative concentrations of the detected fatty acids. Peaks were identified by reference to the retention of FAME standards and quantified by the aid of heptadecanoic acid (17:0) as an internal standard. The concentration of each fatty acid was calculated as a percentage $(w / w)$ of the total fatty acids. 


\subsection{Statistical Analysis}

All data were analyzed using the Analysis of Variance procedures in version 9.3 of SAS (SAS, 2013) significance of mean squares was tested at 1 and $5 \%$ levels. The means were compared using Fisher's Protected Least Significant Difference at a 5\% level of significance.

\section{Results and Discussion}

\subsection{Cultivars, Planting Dates, and Row Spacing Effects on Oil Yield}

Oil yields were significantly affected by planting dates and row spacings (Table 1). Early planting (late May to early June) resulted in $716.6 \mathrm{~kg}$ oil $/ \mathrm{ha}$ as compared to $479.6 \mathrm{~kg}$ oil/ha from late planting (early June to mid-July), an increase of about 1.5 times (Table 2). Differences among five sesame cultivars for oil yield were not significant (Table 3). The closer row spacing of $37.5 \mathrm{~cm}$ out-yielded the wider row spacing of $75 \mathrm{~cm}$ by about 34 $\%$ for oil yield (Table 4$)$.

Table 1. Partial analysis of variance (Mean squares) for oil yield and contents of fatty acids in five sesame cultivars grown using two planting dates and two row spacings in Virginia during 2011 and 2012

\begin{tabular}{|c|c|c|c|c|c|c|c|c|c|}
\hline Variable & $\begin{array}{l}\text { Planting dates } \\
\text { (PD) }\end{array}$ & $\begin{array}{l}\text { Row spacings } \\
\text { (RS) }\end{array}$ & $\begin{array}{l}\text { Cultivars } \\
\text { (C) }\end{array}$ & $\mathrm{PD} \times \mathrm{RS}$ & $\mathrm{PD} \times \mathrm{C}$ & $\mathrm{RS} \times \mathrm{C}$ & $\mathrm{R}^{2} \%$ & $\mathrm{CV} \%$ & Mean \\
\hline Oil yield $(\mathrm{kg} / \mathrm{ha})$ & $*$ & $* *$ & ns & $* *$ & $*$ & $*$ & 87.7 & 31.6 & 598.1 \\
\hline$C 16: 0^{x}$ & $* *$ & ns & $*$ & ns & $\mathrm{ns}$ & ns & 98.4 & 0.97 & 8.8 \\
\hline$C 18: 0^{x}$ & ns & ns & ns & $* *$ & ns & $*$ & 98.9 & 0.68 & 5.2 \\
\hline$C 20: 0^{x}$ & $* *$ & $*$ & ns & $* *$ & $\mathrm{~ns}$ & $\mathrm{~ns}$ & 94.3 & 2.02 & 0.57 \\
\hline $\mathrm{C} 22: 0^{\mathrm{x}}$ & $\mathrm{ns}$ & $*$ & ns & $* *$ & ns & ns & 94.9 & 20.83 & 0.11 \\
\hline C16: $1^{x}$ & $\mathrm{~ns}$ & $\mathrm{~ns}$ & ns & $* *$ & $*$ & ns & 93.2 & 9.86 & 0.11 \\
\hline $\mathrm{C} 18: 1^{\mathrm{x}}$ & $*$ & ns & $*$ & $* *$ & ns & $\mathrm{ns}$ & 97.7 & 1.70 & 38.3 \\
\hline$C 18: 2^{x}$ & $*$ & ns & $* *$ & ns & ns & $\mathrm{ns}$ & 99.2 & 0.91 & 46.2 \\
\hline$C 18: 3^{x}$ & * & $\mathrm{ns}$ & $\mathrm{ns}$ & ns & ns & ns & 88.7 & 9.21 & 0.39 \\
\hline $\mathrm{C} 20: 1^{\mathrm{x}}$ & $*$ & $* *$ & ns & $* *$ & ns & $\mathrm{ns}$ & 98.7 & 9.15 & 0.17 \\
\hline $\mathrm{SFA}^{\mathrm{y}}$ & $* *$ & $* *$ & $* *$ & $*$ & ns & ns & 98.8 & 0.60 & 14.7 \\
\hline $\mathrm{UFA}^{\mathrm{y}}$ & $*$ & ns & $*$ & $* *$ & ns & ns & 90.1 & 0.62 & 85.3 \\
\hline MUFA $^{y}$ & $*$ & ns & $*$ & $* *$ & ns & ns & 97.7 & 1.69 & 38.6 \\
\hline PUFA $^{\mathrm{y}}$ & $*$ & $\mathrm{~ns}$ & $* *$ & ns & ns & $\mathrm{ns}$ & 99.3 & 0.90 & 46.6 \\
\hline RATIO $^{y}$ & ns & $\mathrm{ns}$ & ns & $\mathrm{ns}$ & ns & ns & 86.3 & 9.04 & 119:1 \\
\hline
\end{tabular}

Note. ${ }^{*}, * *$ : Mean squares significantly different from residual mean squares at 5 and 1 percent levels, respectively.

$\mathrm{x}$ : Fatty acids as percentage of total fatty acids.

y: SFA = Saturated fatty acids; UFA = Unsaturated fatty acids, MUFA = Mono-unsaturated fatty acids; PUFA = Poly unsaturated fatty acids; Ratio $=\mathrm{C} 18: 2 / \mathrm{C} 18: 3$.

\subsection{Cultivars, Planting Dates, and Row Spacing Effects on Fatty Acids}

This study revealed that planting dates significantly effected contents of several fatty acids sesame oil produced in Virginia but did not effect contents of C18:0, C22:0, and C16:1 fatty acids (Table 1). Early planting resulted in increased contents of $\mathrm{C} 16: 0, \mathrm{C} 20: 0, \mathrm{C} 18: 1$, and $\mathrm{C} 20: 1$ fatty acids whereas late planting resulted in increased contents of $\mathrm{C} 18: 2$ and $\mathrm{C} 18: 3$ fatty acids. Contents of total saturated fatty acids and mono-unsaturated fatty acids were also greater after early planting as compared to those after late plantings (Table 2). Thus, early planting resulted in a $2.2 \%$ increase in content of $\mathrm{C} 16: 0,1.7 \%$ increase in the content of $\mathrm{C} 20: 0,7.0 \%$ increase in the content of $\mathrm{C} 18: 1,26.7 \%$ increase in content of $\mathrm{C} 20: 1$, and $7.0 \%$ increase in the content of mono-unsaturated fatty acids. Conversely, late planting resulted in increased contents of C18:2 (+7.6\%), C18:3 (+10.8\%), and poly-unsaturated fatty acids $(+7.8 \%)$ over early planting. Content of omega-3 fatty acid, which is considered 
healthy for human nutrition (Rennie et al., 2003; Freeman, 2000; Holm et al., 2001), in sesame oil was only around $0.4 \%$ as compared to other oilseeds such as canola (Approximately $8 \%$ ). However, increased concentrations of poly-unsaturated fatty acids, such as C18:3) is known to cause oxidative instability in oils Nardini et al., 1995) which necessitates the use of an anti-oxidant such as vitamin E (Gil, 2002).

Table 2. Effects of planting dates on contents of oil yield and fatty acids in five sesame cultivars grown using two row spacings in Virginia during 2011 and 2012

\begin{tabular}{lll}
\hline Variable & Early planting (PT1) & Late planting (PT2) \\
\hline Oil yield (Kg/ha) & $716.6 \mathrm{a}^{*}$ & $479.6 \mathrm{~b}$ \\
$\mathrm{C} 16: 0^{\mathrm{x}}$ & $8.90 \mathrm{a}$ & $8.7 \mathrm{~b}$ \\
$\mathrm{C} 18: 0^{\mathrm{x}}$ & $5.30 \mathrm{a}$ & $5.20 \mathrm{a}$ \\
$\mathrm{C} 20: 0^{\mathrm{x}}$ & $0.57 \mathrm{a}$ & $0.56 \mathrm{~b}$ \\
$\mathrm{C} 22: 0^{\mathrm{x}}$ & $0.11 \mathrm{a}$ & $0.10 \mathrm{~b}$ \\
$\mathrm{C} 16: 1^{\mathrm{x}}$ & $0.12 \mathrm{a}$ & $0.11 \mathrm{a}$ \\
$\mathrm{C} 18: 1^{\mathrm{x}}$ & $39.6 \mathrm{a}$ & $37.0 \mathrm{~b}$ \\
$\mathrm{C} 18: 2^{\mathrm{x}}$ & $44.5 \mathrm{~b}$ & $47.9 \mathrm{a}$ \\
$\mathrm{C} 18: 3^{\mathrm{x}}$ & $0.37 \mathrm{~b}$ & $0.41 \mathrm{a}$ \\
$\mathrm{C} 20: 1^{\mathrm{x}}$ & $0.19 \mathrm{a}$ & $0.15 \mathrm{~b}$ \\
SFA $^{\mathrm{y}}$ & $14.9 \mathrm{a}$ & $14.5 \mathrm{~b}$ \\
UFA $^{\mathrm{y}}$ & $84.8 \mathrm{~b}$ & $85.6 \mathrm{a}$ \\
MUFA $^{\mathrm{y}}$ & $39.9 \mathrm{a}$ & $37.3 \mathrm{~b}$ \\
PUFA $^{\mathrm{y}}$ & $44.8 \mathrm{~b}$ & $48.3 \mathrm{a}$ \\
RATIO $^{\mathrm{y}}$ & $121: 1 \mathrm{a}$ & $117: 1 \mathrm{a}$ \\
\hline
\end{tabular}

Note. *: Means followed by similar letters within rows were not different according to Least Significant Difference test at 5 percent level of significance.

$\mathrm{x}$ : Fatty acids as percentage of total fatty acids.

y: SFA = Saturated fatty acids; UFA = Unsaturated fatty acids; MUFA = Mono-unsaturated fatty acids; PUFA = Poly unsaturated fatty acids; Ratio $=$ C18:2 / C18:3.

In general, contents of various fatty acids in the oil from five cultivars didn't differ significantly perhaps due to limited number of cultivars included in these studies. We expect that evaluations conducted with larger number of cultivars would indicate cultivar differences for oil yield and quality. However, oil of 22K and S32 cultivars contained significantly higher contents of C18:2 and poly-unsaturated fatty acids as compared to the oil of S26 and S28 cultivars (Table 3). 
Table 3. Cultivar differences for contents of oil yield and fatty acids in sesame produced using two row spacings and two planting dates in Virginia during 2011 and 2012

\begin{tabular}{llllll}
\hline Variable & $22 \mathrm{~K}$ & S26 & S28 & S30 & S32 \\
\hline Oil yield (Kg/ha) & $534.4 \mathrm{a}$ & $577.6 \mathrm{a}$ & $543.0 \mathrm{a}$ & $669.5 \mathrm{a}$ & $666.0 \mathrm{a}$ \\
$\mathrm{C} 16: 0^{\mathrm{x}}$ & $8.75 \mathrm{bc}$ & $8.87 \mathrm{ab}$ & $8.95 \mathrm{a}$ & $8.67 \mathrm{c}$ & $8.72 \mathrm{bc}$ \\
$\mathrm{C} 18: 0^{\mathrm{x}}$ & $5.25 \mathrm{a}$ & $5.29 \mathrm{a}$ & $5.29 \mathrm{a}$ & $5.23 \mathrm{a}$ & $5.19 \mathrm{a}$ \\
$\mathrm{C} 20: 0^{\mathrm{x}}$ & $0.57 \mathrm{a}$ & $0.57 \mathrm{a}$ & $0.57 \mathrm{a}$ & $0.57 \mathrm{a}$ & $0.56 \mathrm{a}$ \\
$\mathrm{C} 22: 0^{\mathrm{x}}$ & $0.10 \mathrm{a}$ & $0.11 \mathrm{a}$ & $0.10 \mathrm{a}$ & $0.11 \mathrm{a}$ & $0.11 \mathrm{a}$ \\
$\mathrm{C} 16: 1^{\mathrm{x}}$ & $0.11 \mathrm{a}$ & $0.12 \mathrm{a}$ & $0.12 \mathrm{a}$ & $0.11 \mathrm{a}$ & $0.12 \mathrm{a}$ \\
$\mathrm{C} 18: 1^{\mathrm{x}}$ & $38.1 \mathrm{~b}$ & $38.81 \mathrm{a}$ & $38.3 \mathrm{~b}$ & $38.2 \mathrm{~b}$ & $38.2 \mathrm{~b}$ \\
$\mathrm{C}^{18}: 2^{\mathrm{x}}$ & $46.6 \mathrm{a}$ & $45.6 \mathrm{c}$ & $46.0 \mathrm{bc}$ & $46.4 \mathrm{ab}$ & $46.5 \mathrm{a}$ \\
$\mathrm{C}^{20}: 1^{\mathrm{x}}$ & $0.17 \mathrm{a}$ & $0.17 \mathrm{a}$ & $0.17 \mathrm{a}$ & $0.17 \mathrm{a}$ & $0.18 \mathrm{a}$ \\
SFA $^{\mathrm{y}}$ & $14.7 \mathrm{~b}$ & $14.8 \mathrm{a}$ & $14.9 \mathrm{a}$ & $14.6 \mathrm{~b}$ & $14.6 \mathrm{~b}$ \\
UFA $^{\mathrm{y}}$ & $85.3 \mathrm{a}$ & $85.1 \mathrm{ab}$ & $84.9 \mathrm{~b}$ & $85.2 \mathrm{ab}$ & $85.4 \mathrm{a}$ \\
MUFA $^{\mathrm{y}}$ & $38.3 \mathrm{~b}$ & $39.1 \mathrm{a}$ & $38.6 \mathrm{~b}$ & $38.4 \mathrm{~b}$ & $38.5 \mathrm{~b}$ \\
PUFA $^{\mathrm{y}}$ & $47.0 \mathrm{a}$ & $46.0 \mathrm{c}$ & $46.3 \mathrm{bc}$ & $46.7 \mathrm{ab}$ & $46.9 \mathrm{a}$ \\
RATIO $^{\mathrm{y}}$ & $113: 1 \mathrm{a}$ & $119: 1 \mathrm{a}$ & $121: 1 \mathrm{a}$ & $123: 1 \mathrm{a}$ & $119: 1 \mathrm{a}$ \\
\hline
\end{tabular}

Note. *: Means followed by similar letters within rows were not different according to Least Significant Difference test at 5 percent level of significance.

$\mathrm{x}$ : Fatty acids as percentage of total fatty acids.

y: SFA = Saturated fatty acids; UFA = Unsaturated fatty acids; MUFA = Mono-unsaturated fatty acids; PUFA = Poly unsaturated fatty acids; Ratio $=\mathrm{C} 18: 2 / \mathrm{C} 18: 3$.

It was observed that closer row spacing of $37.5 \mathrm{~cm}$ resulted in significantly higher contents of $\mathrm{C} 20: 1$ and saturated fatty acids in the oil as compared to the wider row spacing of $75 \mathrm{~cm}$. However, the wider row spacing resulted in a significant increase in oil yield (Table 4). In general, effects of closer and wider row spacings on sesame oil quality were not that pronounced. This indicates that sesame can be produced in Virginia by using either of these row spacings. The objectives were to identify optimal row spacing for sesame production in Virginia because farmers, generally, resist purchase of new equipment when initially evaluating production of new, non-traditional crops. Most Virginia farmers own soybean planters either configured for $37.5 \mathrm{~cm}$ or $75 \mathrm{~cm}$ rows and our results indicate that sesame in Virginia could be planted with existing planters. Given that amount of seed for planting is small, it might be desirable to use $37.5 \mathrm{~cm}$ rows because of better weed control due to shading. Moreover, if sesame is to be produced organically using cultivation for weed control then $75 \mathrm{~cm}$ rows might be desirable. 
Table 4. Row spacing effects on contents of oil yield and fatty acids in five sesame cultivars produced using two planting dates in Virginia during 2011 and 2012

\begin{tabular}{|c|c|c|}
\hline Variable & $37.5 \mathrm{~cm}$ & $75 \mathrm{~cm}$ \\
\hline Oil yield $(\mathrm{kg} / \mathrm{ha})$ & $684.4 \mathrm{a}$ & $511.9 \mathrm{~b}$ \\
\hline C16:0 $0^{x}$ & $8.8 \mathrm{a}$ & $8.8 \mathrm{a}$ \\
\hline C18:0 $0^{x}$ & $5.25 \mathrm{a}$ & $5.25 \mathrm{a}$ \\
\hline $\mathrm{C} 20: 0^{\mathrm{x}}$ & $0.57 \mathrm{a}$ & $0.57 \mathrm{a}$ \\
\hline $\mathrm{C} 22: 0^{\mathrm{x}}$ & $0.11 \mathrm{a}$ & $0.10 \mathrm{a}$ \\
\hline C16: $1^{x}$ & $0.11 \mathrm{a}$ & $0.12 \mathrm{a}$ \\
\hline C18: $1^{x}$ & $38.1 \mathrm{a}$ & $38.5 \mathrm{a}$ \\
\hline$C 18: 2^{x}$ & $46.3 \mathrm{a}$ & $46.1 \mathrm{a}$ \\
\hline $\mathrm{C} 18: 3^{\mathrm{x}}$ & $0.39 \mathrm{a}$ & $0.39 \mathrm{a}$ \\
\hline $\mathrm{C} 20: 1^{\mathrm{x}}$ & $0.19 \mathrm{a}$ & $0.15 b$ \\
\hline $\mathrm{SFA}^{\mathrm{y}}$ & $14.7 \mathrm{a}$ & $14.7 \mathrm{a}$ \\
\hline $\mathrm{UFA}^{\mathrm{y}}$ & $85.1 \mathrm{a}$ & $85.1 \mathrm{a}$ \\
\hline MUFA $^{y}$ & $38.4 \mathrm{a}$ & $38.8 \mathrm{a}$ \\
\hline PUFA $^{\mathrm{y}}$ & $46.7 \mathrm{a}$ & $46.5 \mathrm{a}$ \\
\hline RATIO $^{y}$ & $119: 1 \mathrm{a}$ & $119: 1 \mathrm{a}$ \\
\hline
\end{tabular}

Note. *: Means followed by similar letters within rows were not different according to Least Significant Difference test at 5 percent level of significance.

$\mathrm{x}$ : Fatty acids as percentage of total fatty acids.

y: SFA = Saturated fatty acids; UFA = Unsaturated fatty acids; MUFA = Mono-unsaturated fatty acids; PUFA = Poly unsaturated fatty acids; Ratio $=\mathrm{C} 18: 2 / \mathrm{C} 18: 3$.

\subsection{Cultivars, Planting Dates, and Row Spacing Effects on Ratio of C18:2 and C18:3 Fatty Acids}

We also analyzed the oil of sesame produced in Virginia for ratio of C18:2 and C18:3 fatty acids. The ratio of n- 6 and n-3 fatty acids is important for human health and should be in the range of 1:1 to 4:1 whereas in the Western diet it is now estimated to be 10:1 to 30:1 (Raper \& Cronin, 1992; Watkins, 2004). Flaxseed oil has an omega-6:omega-3 ratio of $0.3: 1$. As intake of n-6 fatty acids increased in developed countries, consumption of foods rich in $\mathrm{n}-3$ fatty acids steadily declined. Omega-3 fatty acids constitute a minuscule portion $(<1 \%)$ of the total fatty acids in U.S. food supply whereas the omega-6 fatty acids (Linoleic acid, 18:2) constitute a significant majority. Watkins (2004) summarized the information relative to n-3 and n-6 fatty acids and concluded, without suggesting that insufficiency of n-3 fatty acids in the diet may be the only cause of increased incidence of many human disorders, that insufficiency n-3 fatty acids in Western diets may be at the root cause of many behavioral, learning, memory, and neurological human disorders.

The ratio of C18:2 to C18:3 fatty acids in oil of sesame seeds produced in Virginia averaged 119:1 which is considerably different than the desired ratio from 1:1 to 4:1. In this study, the ratio of C18:2 to C18:3 fatty acids was not affected by planting dates, row spacings, or cultivars. We do not feel comfortable drawing any substantial conclusions based on the results related to the ratio between $\mathrm{C} 18: 2$ and $\mathrm{C} 18: 3$ fatty acids in sesame oil but present the results for use by future investigators.

\subsection{Comparison of Seed Produced in Virginia and Texas}

A comparison of concentrations of oil and fatty acids indicated significant differences between seed produced in Virginia and Texas (Data not presented). Oil content in sesame produced in Virginia was $6.8 \%$ higher than that produced in Texas (45.5 vs. $42.6 \%$, respectively). With regards to individual fatty acids, seed produced in Virginia had significantly higher contents of C18:2 (45.7 vs. $41.5 \%), \mathrm{C} 18: 3$ ( 0.40 vs. $0.36 \%)$, and C22:0 (0.134 vs. $0.128 \%$ ) over seed produced in Texas whereas seed produced in Texas had significantly higher contents of C16:0 (9.3 vs. $8.8 \%$ ), C16:1 (0.13 vs. $0.11 \%$ ), C18:0 (5.5 vs. 5.2\%), C18:1 (42.2 vs. $38.9 \%$ ), and $\mathrm{C} 20: 0$ (0.60 vs. $0.58 \%$ ) fatty acids over seed produced in Virginia. 
We attribute these differences to soil and agro-climatic conditions in Virginia and Texas. Temperature data for Uvalde, Texas where seeds of cultivars included in this study were produced during 2010 indicates that this location was hotter than Petersburg, Virginia location where the five cultivars were evaluated during 2011 (Mean temperatures $\left({ }^{\circ} \mathrm{F}\right)$ of $78,85,84,87,80$, and 72 at Uvalde, Texas during May, June, July, August, September, and October, respectively during 2010 as compared to mean temperatures of 67, 77, 81, 80, 78, and 61 at Petersburg, Virginia during May, June, July, August, September, and October, respectively during 2011. The soil at Uvalde, Texas location is Uvalde silty clay loam (Fine-silty, mixed, hyperthermic Aridic Calciustoll) with a $\mathrm{pH} 8.2$ whereas the soil at Petersburg, Virginia location is Abel sandy loam (Fine loamy mixed thermic Aquatic Hapludult) with a $\mathrm{pH}$ of 6.2. These data indicate that cooler temperature during growing season and sandy soils might be beneficial for better sesame oil yield and quality.

\section{Conclusions}

Overall, the results indicate that Virginia might be a better location for sesame production than Texas for higher oil content and higher content of linolenic acid (C18:3) which is considered desirable for human nutrition. The crop, in general, was identified to be healthy. We didn't observe any insects-pest or disease problems in sesame plots and suggest that sesame could be developed as an alternative summer cash crop for former tobacco farmers in Virginia and elsewhere. It is recommended that sesame be produced by planting early in the summer using a closer row spacing. Our studies show, for the first time, that sesame could be produced in the mid-Atlantic region of USA.

\section{Acknowledgements}

Financial support from Virginia Tobacco Commission (Virginia Tobacco Indemnification and Community Revitalization Commission) is gratefully acknowledged).

\section{References}

AgMRC. (2013). Sesame Profile. Ag Marketing Resource Center. Iowa State University, Ames, IA. Retrieved June 19, 2014, from http://www.agmrc.org/commodities_products/grains_oilseeds/sesame-profile/

Bedigian, D., \& Harlan, J. R. (1986). Evidence for cultivation of sesame in the ancient world. Econ. Bot., 40, 137-154. Retrieved June 19, 2014, from http://link.springer.com/article/10.1007/BF02859136\#

Betts, E. M. (1999). Thomas Jefferson's garden book (1766-1824). Thomas Jefferson Memorial Foundation, Inc., Charlottesville, VA. $\quad$ Retrieved June 19, 2014, from http://www.amazon.com/Thomas-Jeffersons-Garden-Book-1766-1824/dp/1432588893

Freeman, M. P. (2000). Omega-3 fatty acids in psychiatry: A Review. Annals of Clinical Psychiatry, 12, 159-165. Retrieved June 19, 2014, from http://www.ncbi.nlm.nih.gov/pubmed/10984006

Gil, A. (2002). Polyunsaturated fatty acids and inflammatory diseases. Biomedicine and Pharmacotherapy, 56, 388-396. Retrieved June 19, 2014, from http://www.ncbi.nlm.nih.gov/pubmed/12442911

Hamama, A. A., Bhardwaj, H. L., \& Starner, D. E. (2003). Genotype and Growing Location effects on Phytosterols in Canola Oil. J. Am. Oil Chem. Soc., 80, 121-1126. http://dx.doi.org/10.1007/s11746-003-0829-3

Hoffman, A., \& Claassen, C. E. (1949). Sesame research in progress at the University of Nebraska (pp. 36-37). I Proc. First Int. Sesame Conf., Clemson Agricultural College, Clemson, SC. Retrieved from http://www.hort.purdue.edu/newcrop/ncnu02/v5-157.html

Holm, T., Andreassen, A. K., Aukrust, P., Andersen, K., Geiran, O. R., Kjekshus, J., ... Gullestad, L. (2001). Omega-3 fatty acids improve blood pressure control and preserve renal function in hypertensive heart transplant recipients. European Heart Journal, 22, 428-436. http://dx.doi.org/10.1053/euhj.2000.2369

Kalton, R. (1949). Sesame, a promising new oilseed crop for Texas (pp. 62-66). Proc. First Int. Sesame Conference, Clemson Agricultural College, Clemson, SC. Retrieved from http://www.hort.purdue.edu/newcrop/ncnu02/v5-157.html

Langham, D. R., \& Wiemers, T. (2002). Progress in mechanizing sesame in the US through breeding. In J. Janick \& A. Whipkey (Eds.), Trends in New Crops and New Uses (pp. 157-173). ASHS Press, Alexandria, VA. Retrieved June 19, 2014, from http://www.hort.purdue.edu/newcrop/ncnu02/v5-157.html

Martin, J. A. (1949). Improvement of sesame in South Carolina (pp. 71-73). Proc. First Int. Sesame Conf., Clemson Agricultural College, Clemson, SC. Retireved from http://www.hort.purdue.edu/newcrop/ncnu02/v5-157.html 
Nardini, M., DAquino, M. D., Gentili, V., DiFelice, M., \& Scaccini, C. (1995). Dietary fish oil enhances plasma and LDL oxidative modification in rats. Journal of Nutritional Biochemistry, 6, 474-480. http://dx.doi.org/10.1016/0955-2863(95)00081-A

Raper, N. R., Cronin, F. J., \& Exler, J. (1992). Omega-3 fatty acid content of the US food supply. J. Am. Coll. Nutr., 11, 304-308. http://dx.doi.org/10.1080/07315724.1992.10718231

Rennie, K. L., Hughes, J., Lang, R., \& Jebb, S. A. (2003). Nutritional management of rheumatoid arthritis: A review of the evidence. Journal of Human Nutrition and Dietetics, 16, 97-109. http://dx.doi.org/10.1046/j.1365-277X.2003.00423.x

SAS. (2013). SAS System for Windows. SAS Institute, Inc., Cary, NC. Retrieved from http://www.sas.com/en_us/software/sas9.html

USDA. (2009). Census of Agriculture. National Agricultural Statistical Service (NASS), US Department of Agriculture, Washington, D.C.

Watkins, C. (2004). Fundamental fats. INFORM, 15, 638-640. Retrieved June 19, 2014, from http://aocs.files.cms-plus.com/inform/2004/10/fundamental.pdf

\section{Copyrights}

Copyright for this article is retained by the author(s), with first publication rights granted to the journal.

This is an open-access article distributed under the terms and conditions of the Creative Commons Attribution license (http://creativecommons.org/licenses/by/3.0/). 